\title{
Effects of Residual Oxygen in the Degradation of the Performance of Organic Bulk Heterojunction Solar Cells: Stability, Role of the Encapsulation
}

\author{
Vianou Irénée Madogni1,2*, Macaire Agbomahéna ${ }^{3,4}$, Basile Bruno Kounouhéwa1,2,5, \\ Olivier Douhéret ${ }^{3}$, Roberto Lazzaroni ${ }^{3}$
}

\author{
${ }^{1}$ Département de Physique (FAST), Formation Doctorale Sciences des Matériaux (FDSM), Université d’Abomey, Calavi, Bénin \\ ${ }^{2}$ Laboratoire de Physique du Rayonnement LPR, FAST-UAC, Cotonou, Bénin \\ ${ }^{3}$ Laboratory for Chemistry of Novel Materials, Materia Nova R\&D Center, University of Mons (UMONS), Mons, Belgium \\ ${ }^{4}$ Laboratoire de Caractérisation Thermophysique des Matériaux et Appropriation Energétique (Labo CTMAE/EPAC/UAC), \\ Cotonou, Benin \\ ${ }^{5}$ Centre Béninois de la Recherche Scientifique et Technique (CBRST), Cotonou, Bénin \\ Email: ^madognimadogni@gmail.com
}

How to cite this paper: Madogni, V.I., Agbomahéna, M., Kounouhéwa, B.B., Douhéret, O. and Lazzaroni, R. (2018) Effects of Residual Oxygen in the Degradation of the Performance of Organic Bulk Heterojunction Solar Cells: Stability, Role of the Encapsulation. Advances in Materials Physics and Chemistry, 8, 321-339. https://doi.org/10.4236/ampc.2018.89022

Received: February 20, 2016

Accepted: September 8, 2018

Published: September 11, 2018

Copyright $\odot 2018$ by authors and Scientific Research Publishing Inc. This work is licensed under the Creative Commons Attribution International License (CC BY 4.0).

http://creativecommons.org/licenses/by/4.0/

\begin{abstract}
We have shown in our first articles [1] [2] that even after encapsulation, the first rapid phase of degradation mechanism observed has been attributed to oxidation of interfaces and an alteration of the charges collection process. A second phase slower is induced by the oxidation of the active film, namely a decrease in the absorption and a degradation of the charge transport process. We revealed that another decrease in power conversion efficiency which has been induced by a possible interfacial passivation occurred at the organic/cathode interface, owing to the presence of residual oxygen, moisture and other impurities. This is in reality the real cause of the first rapid phase of degradation mechanism observed.
\end{abstract}

\section{Keywords}

Encapsulation, Alteration, Oxidation, Residual Oxygen, Moisture, Impurities

\section{Introduction}

There are four main stimuli that cause OPVs to age: light, oxygen, water, and heat. Under the exposure to humid air, or at high temperature, the fundamental degradation mechanisms in organic semiconductors as well as its interface 
structure have only been partially understood [2] [3]. Degradation mechanism of organic bulk heterojunction solar cells has been studied to a certain extent from the chemical, structural, and electrical aspects; remaining is a big challenge to develop stable OPVs with a high PCE. Obviously, a comprehensive understanding of the degradation mechanism of OPVs is a prerequisite for the development of efficient OPVs [4]-[14]. Polythiophenes are well investigated due to the ambient stability, and therefore current state-of-the-art polythiophene based OPVs employ morphologically stable bulk heterojunction of regioregular poly (3-hexylthiophene) (P3HT) as the donor and the soluble phenyl- $\mathrm{C}_{61}$-butyric acid methyl ester (PCBM) as the acceptor. Their reactions with oxygen and water occur not only in the volume, but also at the interfaces of these layers [15] [16] [17]. In addition, the role of water in the degradation process also remains unclear. In the presence of moisture, the $\mathrm{P} 3 \mathrm{HT}$ photooxidation rate will in general be increased, whereas it does not seem to play a role if there is no oxygen in ambiance [18].

The quality and type of encapsulation play an important role in the stability and overall lifetime of the device by limiting the amount of oxygen and water molecules that permeate the device as well as preventing UV exposure through the utilization of UV filtering encapsulation. UV-blocking layers can increase the long term stability of organic solar cell devices by filtering out UV radiation [19]. $\mathrm{TiO}_{\mathrm{x}}$ layers have been used effectively as UV-blocking layers in P3HT:PCBM inverted organic OPVs and it has been observed that device stability increases with increasing $\mathrm{TiO}_{\mathrm{x}}$ film thickness [20]. In P3HT:PCBM devices with a normal architecture, $\mathrm{TiO}_{2}-\mathrm{SiO}_{\mathrm{x}}$ layers have been successfully used to block UV radiation [21]. Similarly, a luminescent layer has been inserted on top of the UV-blocking layer in order to enable photon recycling, thus enhancing device performance.

There are many different materials that can be used to encapsulate OPVs and they vary considerably in both effectiveness and cost. One of the simplest packaging options available is to cover the device with glass plates and use an epoxy-type sealant to hold them in place [22]. This configuration provides effective protection against oxygen and moisture to the device, but is not suitable for the production of flexible devices. Gold, flexibility is one of the key advantages of OPVs [23]. Several research efforts are focused on developing an encapsulation material that will be flexible and at the same time have all the above advantages, i.e. adequate protection to the device, transparency and low-cost. Several inorganic materials have been used for encapsulating solar cells with varying degrees of success. Single layer, silicon-based dielectric films deposited by plasma-enhanced chemical vapor deposition have been used as encapsulating materials, and their oxygen and water transmission rates have been studied [24] [25]. Thin oxide films such as $\mathrm{TiO}_{2}$ and $\mathrm{Al}_{2} \mathrm{O}_{3}$ have also been used, although these films are still permeable to some degree by water molecules, mainly due to pinhole defects or to the existence of pores on their surface [26]. $\mathrm{Al}_{2} \mathrm{O}_{3}$ films depo- 
sited by Atomic Layer Deposition (ALD) have been used, either on their own, or in combination with a UV sealant for pentacene- $\mathrm{C}_{60}$ based solar cells [27]. The single $\mathrm{Al}_{2} \mathrm{O}_{3}$ layer was found to be the most effective sealant, preventing cell degradation to a large degree only $6 \%$ loss after over 6000 hours of exposure to ambient atmospheric conditions (but not accelerated).

More recently, ultrathin $\mathrm{Al}_{2} \mathrm{O}_{3}$ layers have been used as encapsulation barriers for P3HT:PCBM OPVs, deposited by a different ALD method [28]. In this study, $\mathrm{H}_{2} \mathrm{O}$ has been replaced with $\mathrm{O}_{3}$ as the ALD oxidant and it has been shown that the $\mathrm{Al}_{2} \mathrm{O}_{3}$ layers deposited using $\mathrm{O}_{3}$ displayed superior device encapsulation compared to the films deposited using $\mathrm{H}_{2} \mathrm{O}$ and retained $80 \%$ of their efficiency after 500 hours in air. But, the use of an ALD technique may not be practical for large-scale commercial applications, mainly due to the long times required for film development. Also, the prolonged heating of the devices at high temperatures (over $100^{\circ} \mathrm{C}$ ) that is required for encapsulating the devices may increase device degradation [28].

Various polymer composites have also been used as OPVs encapsulants, such as polyisobutene (PIB) and ethylene vinyl acetate (EVA) [29] [30]. A polymer encapsulant for OPVs devices has also been developed using polymer nanotube composites based on a copolymer of vinylidene chloride and acrylonitrile [31]. The effectiveness of such sealants has been tested on P3HT films and it has been reported that the encapsulants provide effective protection against atmospheric degradation, have excellent transparency in the visible region and good thermal stability [31]. These results are promising for OPVs applications, but the degradation of complete devices encapsulated with this material has not been investigated to date. Flexible P3HT:PCBM modules have also been encapsulated using commercial barrier foil and average efficiencies of approximately $40 \%$ of the original values have been observed after approximately 1000 hours of outdoor exposure [32]. ITO-free inverted OPVs with $\mathrm{Cr} / \mathrm{Al} / \mathrm{Cr}$ as a bottom electrode and a metal grid on top have been encapsulated using commercial barrier foils and have been found to exhibit a lifetime of more than 1000 hours under damp-heat accelerated lifetime conditions [33]. Polyurethane has also been used to encapsulate inverted OPVs with P3HT:PCBM as well as commercial active layer materials and it has been shown that cells encapsulated with polyurethane retain on average $40 \%$ of their efficiency after more than 3000 hours of outdoor exposure [16]. In another study, non encapsulated cells have been tested and compared with cells protected using three different encapsulation methods: an inorganic $\mathrm{SiO}_{\mathrm{x}}$ film, an organic layer of Kapton tape (polyimide film with silicone adhesive) and a glass/thermoplastic layer [34]. It has been observed that all encapsulation methods improved the stability of the device and that films encapsulated with the inorganic $\mathrm{SiO}_{\mathrm{x}}$ film lost the smallest percentage of their original efficiency overtime.

Most organic films used for encapsulation can be considered homogeneous with regard to their thicknesses, while inorganic films tend to have more defects 
and irregularities. Hybrid inorganic/organic films utilize the properties of both inorganic and organic materials in order to achieve ultra-high barrier properties. These films are structured as multilayer stacks comprised of inorganic oxide layers separated by polymer layers. Inorganic layers have high intrinsic barrier properties, while the organic layers give more flexibility to the final material and eliminate some of the defects that cause water permeation in inorganic materials. An added advantage is that these films can be developed using roll-to-roll processes. Hybrid $\mathrm{Al}_{2} \mathrm{O}_{3}$ /polyethylene terephthalate ( $\mathrm{PET}$ ) films with excellent barrier properties has been developed and a methodology for assessing the properties of such films has been proposed [35] [36]. Attempts to create flexible packaging for various organic devices using such a hybrid multilayer barrier have also been reported elsewhere with promising results [26] [37].

The hybrid ultra-high barrier materials have also been used in OPVs and have shown excellent protective abilities against atmospheric agents. Flexible poly (ethylene naphthalate) (PEN) substrates have been used, coated with ultra-high barrier foils and sealed with epoxy resin [38]. The ultra-high barrier coatings were made from alternating layers of inorganic $\left(\mathrm{SiO}_{\mathrm{x}}\right)$ material and plasma-deposited organic material (organosilicon) sealed together with an epoxy resin and shelf lifetimes over 3000 hours have been reported for MDMO-PPV:PCBM devices sealed with this material [39]. It was observed that the efficiency of the cells was reduced when using the flexible foils compared to the rigid ones. However, the stability of the cells encapsulated with the flexible material was found to be considerably high and a 6000 hours shelf lifetime $(50 \%$ of original efficiency) was recorded for the P3HT:PCBM flexible devices [40].

In recent years, the ternary chalcopyrite semiconductors have been receiving considerable attention because of their adaptability, as an absorber component, in thin film solar cells. AgInSe $e_{2}$ is a ternary analogue of CdSe, which has been used for a number of electronic devices [41]. KrF pulse UV excimer laser ablation of films of $\mathrm{AgInSe}_{2}$ (AIS) onto the glass substrates kept at different temperature using an ultra-high-vacuum deposition system has been studied [42]. The structural, optical and electrical properties have been investigated as functions of the substrate temperature. An increase in substrate temperature results in a more ordered structure. The roughness of the film is found to increase at higher deposition temperatures. The optical studies of the films show that the optical band gap lies in the range $1.20-1.27 \mathrm{eV}$. The activation energy is in the range $0.0103-0.0556 \mathrm{eV}$.

More recently, AgInSe 2 -PCBM:P3HT inorganic organic blends for hybrid bulk heterojunction photovoltaics have been study [43]. The best performance and photovoltaic parameters, we obtained with a spun speed of $600 \mathrm{rpm}$ was an open-circuit voltage $\mathrm{V}_{\mathrm{OC}}$ of about $0.50 \mathrm{~V}$ and a photocurrent density $\mathrm{J}_{\mathrm{SC}}$ of $3.71\left(\mathrm{~mA} / \mathrm{cm}^{2}\right)$ and an efficiency of $0.758 \%$ using a white light illumination intensity of $100 \mathrm{~mW} / \mathrm{cm}^{2}$. Pathak, D. et al., investigated the photovoltaic performance of $\mathrm{AgInSe}_{2}$-conjugated polymer hybrid system bulk heterojunction solar 
cells. The best performance and photovoltaic parameters, that they have obtained was an open-circuit voltage $\mathrm{V}_{\mathrm{OC}}$ of about $0.54 \mathrm{~V}$ and a photocurrent of $\mathrm{J}_{\mathrm{SC}} 117 \mathrm{~mA}$ and an efficiency of $0.2 \%$ using a white light illumination intensity of $23 \mathrm{~mW} / \mathrm{cm}^{2}$ [44].

A comparative assessment of various sealants for small-molecule organic solar cells has also been conducted [45]. In this study, organic (PET), organic/inorganic (zinc tin oxide on PET substrates) encapsulants have been compared with a glass packaging sealed with a UV-activated epoxy resin. The glass encapsulant has found to provide the best protection against water permeation, while one of the organic/inorganic encapsulants yielded the second-best performance, demonstrating the efficacy of the hybrid materials as flexible sealants for OPVs devices. Multilayer barriers of parylene and aluminum oxide coatings have also been shown to provide good protection from atmospheric agents to P3HT:PCBM based OPVs devices for several hours under illumination (three times higher lifetime in the presence of multilayer barrier), and such coatings successfully protect P3HT layers from atmospheric degradation [46] [47]. Although the organic encapsulants are not as effective in sealing the device as glass or hybrid barriers, they are more flexible than the glass ones and they have lower cost than the hybrid barriers as well. The epoxy resins that are often used to seal the devices contain traces of moisture or oxygen unless a degassing process is performed.

In order to eliminate traces of moisture, a getter sheet can be included on the inside of the packaging layer [48]. There is a wide variety of getter materials that can be used for this purpose, including zeolite in various forms, oxides such as $\mathrm{BaO}$ or $\mathrm{CaO}$, reactive metals such as $\mathrm{Ba}$, or $\mathrm{CaO}$ nanoparticles [49]. Highly transparent and easy to process liquid getters have also been developed. The effectiveness of glass encapsulants with and without a liquid getter-filled barrier has been compared, and it has been shown that the barrier properties of the liquid getter-filled encapsulation is comparable with that of the conventional glass encapsulation and gives the advantage of improved thermal properties [50].

Promising results have been reported for inverted OPVs with glass encapsulation that includes a getter layer to ensure that minimum water molecules remain inside the device and a comparative assessment of the lifetime of inverted P3HT:PCBM OPVs with and without encapsulation has been conducted [51]. The packaging in this case was achieved with a glass plate with water getter sheet coated by an epoxy-UV resin as sealing material. The encapsulation increased the lifetime of the device from 20 hours to well over 120 hours under illumination. In large area $\left(233 \mathrm{~cm}^{2}\right)$ P3HT:PCBM OPVs modules have also been produced and sealed with a glass sheet and getter encapsulation system whose lifetime under illumination has been estimated to over 5000 hours [52]. Using a similar type of encapsulation, a lifetime approaching seven years under illumination has been achieved for PCDTBT/PC ${ }_{70} \mathrm{BM}$ OPVs devices [53].

Recently, Adams et al., designed a P3HT:PCBM/pDPP5T-2:PC70BM organic 
tandem solar cell with an inverted device geometry. The cell was sealed with a glass encapsulant and a UV curable epoxy resin. After 2000 hours under illumination the device retained $89 \%$ of its efficiency. By extrapolating this value to $80 \%$ of the initial PCE, an accelerated lifetime of $>10$ years can be estimated. Even though providing an impermeable barrier against water and oxygen is crucial to the performance of OPVs devices, the ease and cost of the encapsulation process are, in the end, the most important parameters in choosing encapsulating materials. Recent studies have shown that commercial PET films can be easily deposited on P3HT:PCBM OPVs using a roll-to-roll process and they provide adequate protection against atmospheric agents to the devices [54]. This process allows for the production of large-scale flexible OPV devices with improved lifetimes compared to non-encapsulated devices. The above process has been enhanced by not only covering the device with a polymer layer, but also by adding protection to the sides through an additional encapsulation step [55]. It has been shown that sealing of the edges of the device considerably increases its stability and that edge-sealed devices have almost constant efficiency for over 1000 hours of operation under illumination [55]. OPVs have also been printed directly on barrier foil and encapsulated with the same barrier foil [56]. In this case, three different adhesives have been used to seal the solar cells: PSA, UV-curable glue, and hotmelt. It was observed that a single-sided lamination with UV-curable epoxy resin achieved the best performing encapsulation over a test period of 900 hours and presented the additional advantages of being a low-cost and relatively fast encapsulation process. Krebs et al., also printed OPVs directly on barrier foil by employing a newly-designed front electrode grid. They achieved efficient edge sealing by printing a UV-curable adhesive on the encapsulation barrier foil and later pierced the devices to allow access to the electrodes. This method is fast and low-cost and the resulting devices are expected to have high stability and lifetime [57].

P3HT:PCBM devices utilizing an inverted architecture have also been shown to retain more than $50 \%$ of their initial efficiency after 4700 hours of continuous exposure to one-sun intensity at elevated temperatures [58]. Several studies have reported favorable progress towards the understanding of degradation mechanisms under different environmental conditions, such as light, moisture, oxygen and heat. This understanding has led to the development of new materials and device structures that have been efficiently used to limit OPVs degradation and improve device lifetime. Moreover, methods for protecting OPVs have been developed, that concentrate on sealing the device from various environmental agents. These encapsulation techniques have led to the development of OPVs devices with increased stability and lifetime. The product development targets of OPVs however, demand flexibility and low-cost encapsulation as well. Although there are a number of low-cost, flexible options that provide adequate protection to the device, a deeper understanding of the degradation parameters is required to provide material design rules and device engineering concepts towards 
low-cost and long-lived flexible OPVs.

The objective of this paper is to study the effects of residual oxygen in the degradation of the performance of organic bulk heterojunction devices: ITO/PEDOT:PSS/rrP3HT:PC70BM (1:0.7 weight ratio)/Yb/Al, upon exposure to a temperate (Belgium) and a sub-equatorial (Benin) from the experimental data that we dispose. The degradation due to the interfacial passivation could be eliminated by the removal of low work function cathode at the sacrifice of power conversion efficiency. Our global objective is very clear supply the electricity for people who have not access to conventional electricity, but lying in areas under strong solar illumination especially in undeveloped countries (Benin).

The rest of this paper is organized as follows: in Section 2, we describe in the experimental procedure, both encapsulation techniques used in this work.

The results and discussions are presented in Section 3. Finally, the conclusion and outlook are listed in Section 4.

\section{Experimental Procedure}

We used two encapsulation techniques:

- Glass encapsulation (rigid encapsulation);

- Encapsulation by Atomic Layer Deposition (ALD) potentially appropriated for all types of substrates, and therefore the flexible structures.

\subsection{Atomic Layer Deposition (ALD) Encapsulation}

This process allows depositing the oxides $\left(\mathrm{Al}_{2} \mathrm{O}_{3}, \mathrm{TiO}_{2}\right.$, and $\left.\mathrm{ZnO}\right)$, semi-metallic elements (Ir, $\mathrm{Ru}, \mathrm{Pd}$, and $\mathrm{Pt}$ ) or nitrides ( $\mathrm{TaN}, \mathrm{TiN})$. The principle consists to successively expose the sample surface at different chemical precursors (forerunners). These precursors react chemically with the surface sequentially, generating a dense film thickness controlled by chemisorption. We used trimethyl aluminum $\left(\mathrm{Al}_{2}\left(\mathrm{CH}_{3}\right)_{6}\right)$ and water $\left(\mathrm{H}_{2} \mathrm{O}\right)$ as precursors in this work. Metallic oxide deposited is therefore the alumina $\left(\mathrm{Al}_{2} \mathrm{O}_{3}\right)$. The substrate is deposited in a primary vacuum glove box $\left(10^{-1}\right.$ torr), at a temperature about $70^{\circ} \mathrm{C}$ attached by the user. The injection of different precursors is done alternately as follows:

- TMA is sent by a flux of $\mathrm{N}_{2}$ in the glove box. By chemisorption, aluminum attaches at the sample surface. The aluminum atoms thereby form a monolayer, keeping their electronic layer of valence incomplete;

- Water is injected under vapor phase. The oxygen atoms react with aluminum (Al) to form alumina $\left(\mathrm{Al}_{2} \mathrm{O}_{3}\right)$, dense crystal, solid and transparent. Hydrogen reacts with methyl to form methane, evacuated by the pump;

- Between each injection of precursor, a nitrogen flux evacuates the residues of the previous precursor, during a sufficient time. These evacuations are primordial so that there is not the simultaneous presence of two chemical substances highly reactive;

- The equipment used for Atomic Layer Deposition is of Savannah 100 type manufactured by Cambridge Nanotech. The procedure used for our encap- 
sulation operations by ALD is as follows:

- Glove box temperature $70^{\circ} \mathrm{C}$. Injection of the precursor $\mathrm{H}_{2} 0$ during $0.015 \mathrm{~s}$, waiting-time $15 \mathrm{~s}$;

- Injection of the precursor TMA during $0.015 \mathrm{~s}$, waiting-time $15 \mathrm{~s}$;

- Repeat cycle 3000 times. Film thickness $330 \mathrm{~nm}$.

To test the efficiency of the ALD device, we have led a series of experiments by progressively submitting the cells manufactured to the long exposure times to air and light. Advantage of Atomic Layer Deposition resides in the possibility to effect the metallic oxide deposits under vacuum packed at low temperature. In the circumstances, the minimum temperature of deposit by ALD is around about $60^{\circ} \mathrm{C}$. However, the inconvenience of this technics is the slowness of the process that lasts about 20 seconds by monolayer, either more than 16 hours of deposit.

These successive stages are cyclically repeated several times, in order to obtain a dense layer of the desired thickness (as shown in Figure 1). Each cycle leads to a deposit of an alumina monolayer of $1.1 \AA$ [2].

\subsection{Glass Encapsulation}

The technique uses a glass plate and glue crosslinked. The encapsulation principle is shown in (Figure 2). The encapsulants glasses are beforehand cut up in order to cover the active surface and let accessible the sample edges for the ulterior anodic and cathodic connectors. The system sample + glue + glass are subjected to UV radiation. The devices have been typically fabricated on the glass substrate and encapsulated with a glass in a glove box with both oxygen and moisture levels less than $0.1 \mathrm{ppm}$ (see [2] for more understanding). In definitive, samples are then exposed to air and ambient light for increasing periods of time, to investigate the contribution of $\mathrm{O}_{2}, \mathrm{H}_{2} \mathrm{O}$ and light to the degradation mechanisms. UV-vis absorption spectra are recorded at different ageing times with a Perkin Elmer lambda 6505 spectrometer. Rigid encapsulation is obtained by applying a glass plate over the devices, with a resin (Nagase Chemtex Corporation) that is crosslinked upon 10 min UV exposure.

\section{Results and Discussions}

\subsection{Glass Encapsulation}

Figure 3 shows the evolution of $\eta$ for two sets of cells fabricated in air, subsequently encapsulated with glass, and tested in Benin and Belgium, during a similar time period (500 hours). A very slight degradation of the cells is observed, in both environments. Extrapolation time to a $20 \%$ loss of the initial efficiencies, obtained with a standard linear fit, leads to a lifetime of $2.2 \times 10^{4}$ hours, i.e. two and a half years. This stresses definitely the efficiency of the encapsulation to reduce the degradation process, even for the devices fabricated in air [59]. Similar performances and stability in time observed in both locations for encapsulated samples stored in ambient conditions confirm that the degradation is to be attributed to $\mathrm{O}_{2}$ and $\mathrm{H}_{2} \mathrm{O}$, in presence of residual oxygen, moisture and other im- 
purities, with further enhancement induced by exposure to light. This stability demonstrates the possibility to use P3HT:PCBM-based OPVs in a tropical environment for a fairly long time period. Combined with a fabrication process for which the influence of the environment has been shown to be small, one can definitely consider a full fabrication process and use of OPVs at minor cost in countries like Benin, with abundant solar radiation and limited resources [2].

\section{Effects of Residual Oxygen: Parameters Affected}

Whatever the climatic condition, we remark that, the decrease in the performance of OPVs within the first 24 hours acceleration aging test (Figure 4) and (Figure 5) seems less sensitive to the change in the moisture level, revealing that the first rapid phase of degradation is likely associated with the deterioration occurred at organic/cathode contact, an inevitable interfacial passivation process due to the presence of residual oxygen at $60^{\circ} \mathrm{C}$. The correlation between the initial degradation in OPVs with the possible residual oxygen in the accelerated aging test thus found also supports the results of our previous study of oxygen effect on the stability of P3HT:PCBM based OPVs in air. We have found in our first article [1] [2] that the oxygen exposure causes an oxygen-induced charge traps and hence leads to an imbalanced charge mobility within P3HT:PCBM photoactive layer, which is one of the major degradation pathways in OPVs. This result has been confirmed by [60]. The first rapid degradation of OPVs observed in our accelerated aging test correlates strongly with the interfacial passivation at organic/cathode interface, as illustrated in (Figure 4, Figure 5, Figure 6) albeit not identical to carrier mobility studies, if direct expose to oxygen/air can be exploited.

We determined the electric parameters for both the (J-V) curves measured in the dark and under illumination after fitting the experimental data to the mathematic model over the entire voltage range. We remarked that under illumination, both $R_{S}$ and $R_{p}$ increase about $10 \%$ after the accelerated aging in the

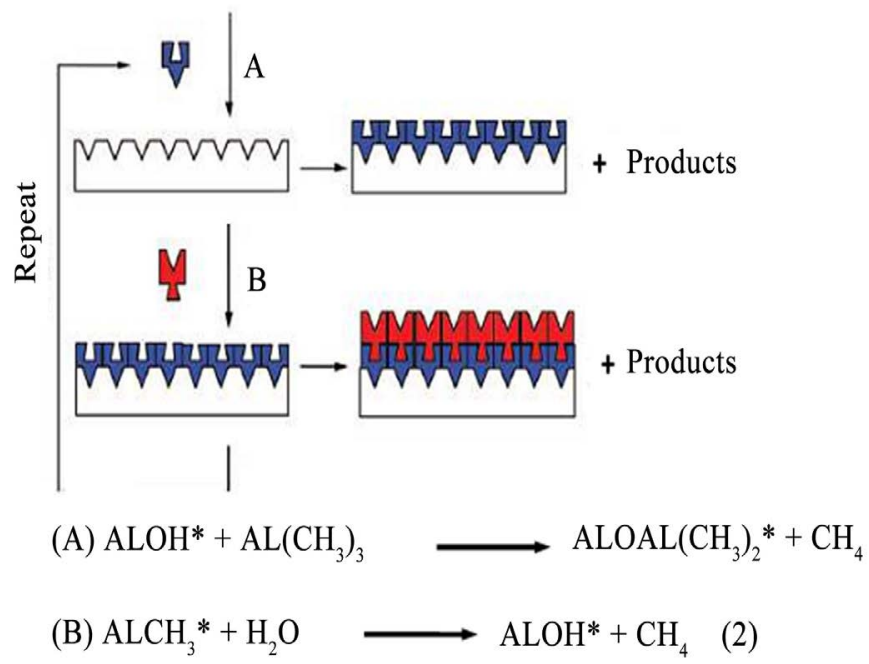

Figure 1. Alumina $\left(\mathrm{Al}_{2} \mathrm{O}_{3}\right)$ deposit cycles by ALD. 


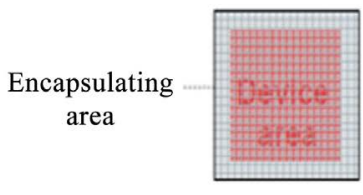

(a)

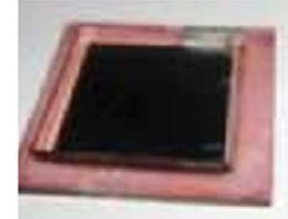

(c)

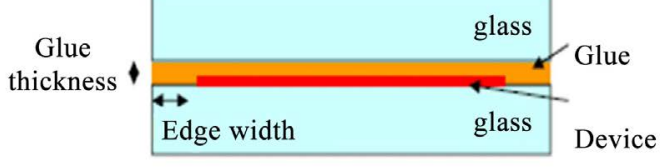

(b)

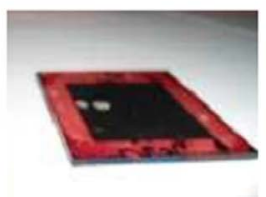

(d)

Figure 2. (a) and (b) Principle of glass encapsulation, (c) Device encapsulated by glass, (d) Device encapsulated by ALD. This Figure shows an example of devices encapsulated by glass and those encapsulated by Atomic Layer Deposition (ALD).

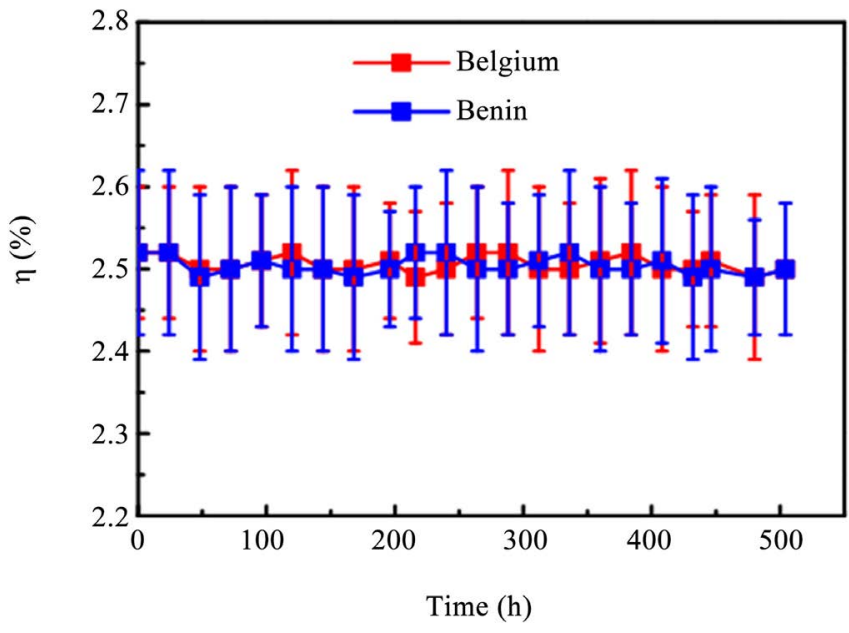

Figure 3. Variations of $\eta$ for two sets of encapsulated cells characterized in Belgium (red) and in Benin (blue). Between measurements the cells are stored in air and exposed to ambient illumination [2].

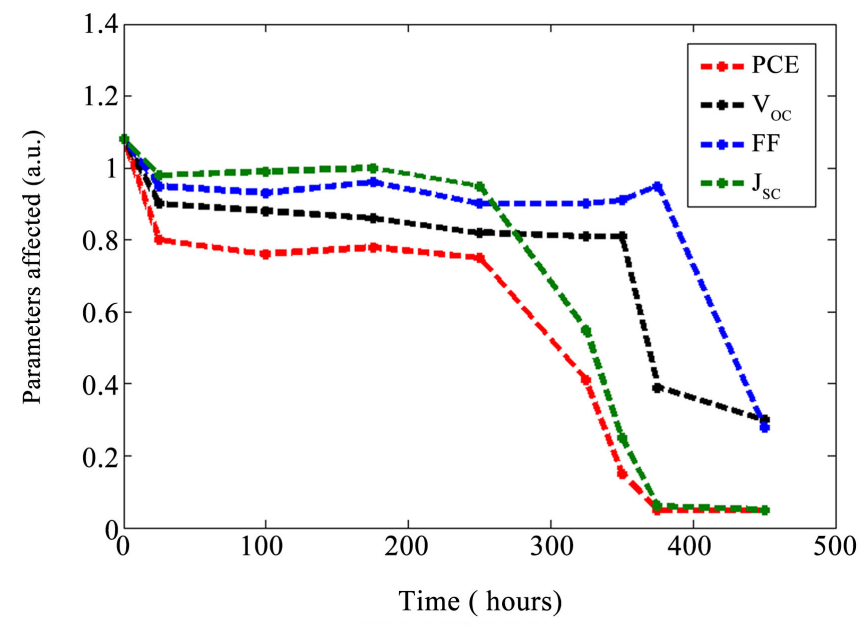

Figure 4. $\mathrm{J}_{\mathrm{SC}}, \mathrm{V}_{\mathrm{OC}}, \mathrm{FF}$ and PCE versus aging time measured for encapsulated OPVs. Devices encapsulated with glass, aged under a $90 \%$ relative humidity at $60^{\circ} \mathrm{C}$. 


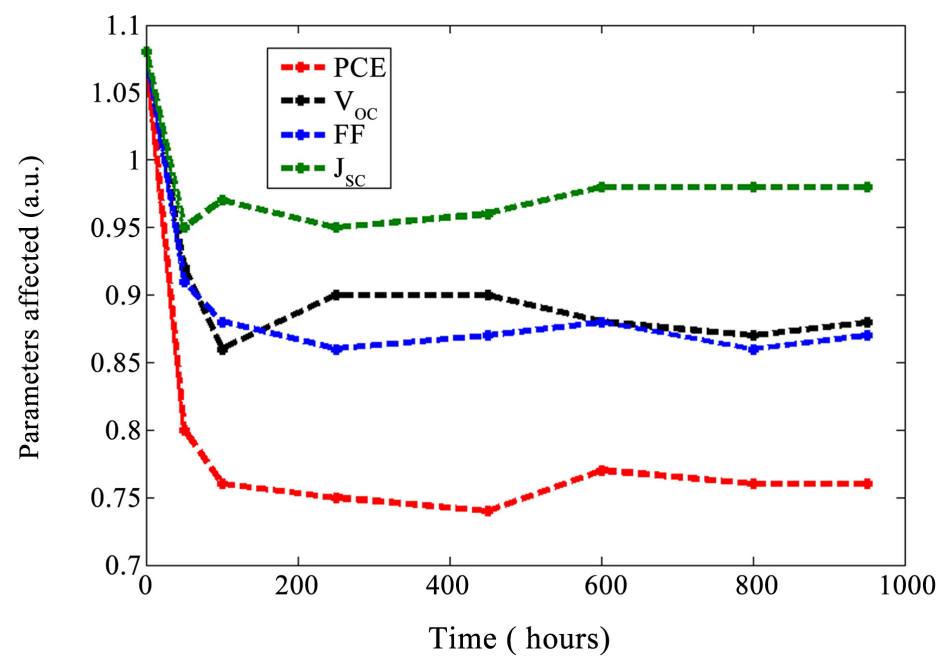

Figure 5. $\mathrm{J}_{\mathrm{SC}}, \mathrm{V}_{\mathrm{OC}}, \mathrm{FF}$ and PCE versus aging time measured for encapsulated OPVs. Devices encapsulated with glass, aged fewer than $5 \%$ relative humidity at $60^{\circ} \mathrm{C}$.

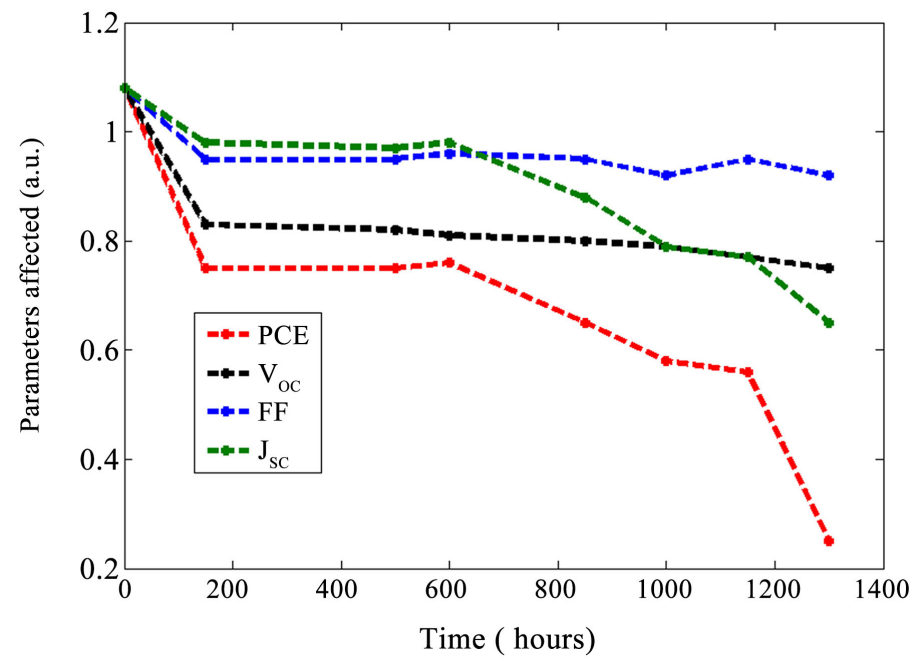

Figure 6. $\mathrm{J}_{\mathrm{SC}}, \mathrm{V}_{\mathrm{OC}}, \mathrm{FF}$ and PCE versus aging time measured for encapsulated OPVs. Devices encapsulated with glass, aged fewer than $90 \%$ relative humidity at $60^{\circ} \mathrm{C}$.

humid chamber for 24 hours. Whereas in the dark, $\mathrm{R}_{\mathrm{S}}$ increases about $10 \%$ and $\mathrm{R}_{\mathrm{p}}$ decreases by as much as threefold after 24 hours. According to the simple model, a high FF can be expected if OPVs possesses both a high parallel shunt resistance and a low series resistance. In this case, a relative reduction of 5\% in FF can be attributed to a combination of the simultaneous decrease in the parallel shunt resistant and an increase in the series resistance in the aged OPVs, for example, about $12 \%$ decrease in the parallel shunt resistance and a $14 \%$ or $16 \%$ increase in the series resistance as observed for OPVs during the first 24 hours.

The decrease in FF, due to the deterioration occurred at the organic/cathode interface, as seen in the change in the series and shunt resistances, implying the role it plays in the first rapid degradation of OPVs observed. Obviously, the more devastating degradation is the quick decrease after 260 hours in Figure 4, 
and this keep son going until the device failure. The short circuit current is kept decreasing during this period, while little reduction in $\mathrm{V}_{\mathrm{OC}}$ and $\mathrm{FF}$ is observed. Furthermore, the degradation of PCE in this stage is primary due to the drop in $\mathrm{J}_{\mathrm{SC}}$, which is different from that in OPVs as shown in Figure 5. As indicated in the literature, in the degradation process of polymeric OPVs, water permeation often plays an important role [1] [2] [14].

Figure 6 shows the evolution of $\mathrm{J}_{\mathrm{SC}}, \mathrm{V}_{\mathrm{OC}}, \mathrm{FF}$ and PCE versus aging time measured for devices encapsulated with glass, aged fewer than $90 \%$ relative humidity at $60^{\circ} \mathrm{C}$. Comparing Figure 4 and Figure 6, both $V_{O C}$ and $F F$ remain stable for a longer period of time than $\mathrm{J}_{\mathrm{Sc}}$. This indicates that moisture induced degradation act differently against the open circuit voltage from the short circuit current density. Globally, we remarked in the first 24 hours, a decrease of about $20 \%$ in PCE is observed; and then the device performs steadily in the next 240 hours, followed by a dramatic decrease to a much lower level and the trend continues till the end. Furthermore, compared with the degradation tendencies of $J_{\mathrm{SC}}$, Voc and FF measured simultaneously, all three parameters play different roles in the decrease of PCE in various time ranges. $\mathrm{V}_{\mathrm{OC}}$ and $\mathrm{FF}$ decrease about $8 \%$ and $12 \%$ in the first 24 hours, while $\mathrm{J}_{\mathrm{SC}}$ remains the same. None of them shows obvious changes up to 260 hours. In definitive, $\mathrm{J}_{\mathrm{SC}}$ drops dramatically, causing a final decline in PCE, until the catastrophic failure after 400 hours.

\subsection{Encapsulation by Atomic Layer Deposition (ALD)}

To test the efficiency of the ALD device, we have done a series of experiments by progressively submitting the cells manufactured at the periods increasingly long under exposure to air and light (Figure 7).

Figure 7 shows the evolution of $\mathrm{J}_{\mathrm{SC}}$ for the accelerated aging test under air and 1 sun during 250 minutes under simulator for the encapsulated devices by ALD and unencapsulated devices. We remarked in the first phase that both series of the devices encapsulated have known a similar decrease of $\mathrm{J}_{\mathrm{SC}}$. A second phase during which $\mathrm{J}_{\mathrm{SC}}$ is stable for the encapsulated devices appears, whereas it progressively decreases for the unencapsulated devices. This observation allows us to conclude that the $\mathrm{Al}_{2} \mathrm{O}_{3}$ layer effectively acts as a barrier layer. This stability of $\mathrm{J}_{\mathrm{SC}}$ induces the stability of the power conversion efficiency during the experimentation period.

\subsection{Comparison}

Compared to ALD encapsulation, glass encapsulation is more effective. We notice that after a few minutes exposure to light under simulator, the values of $\mathrm{J}_{\mathrm{SC}}$ for glass encapsulated devices are stable, while those of other devices notably (ALD encapsulated devices) stabilizes more later to a low value (Figure 8). ALD encapsulation has shown that the alumina slim layer already forms a barrier to the moisture and oxygen even if it abode insufficient to reach the satisfactory lifetime of the devices. 


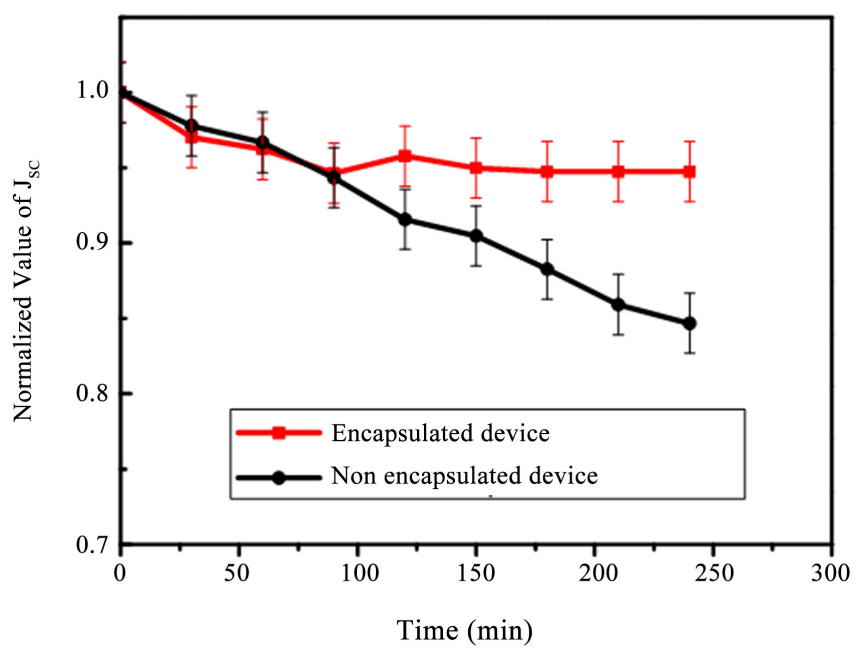

Figure 7. Evolution of $\mathrm{J}_{\mathrm{SC}}$ for the devices unencapsulated (black) and encapsulated by $330 \mathrm{~nm} \mathrm{Al}_{2} \mathrm{O}_{3}$ (red) [2].

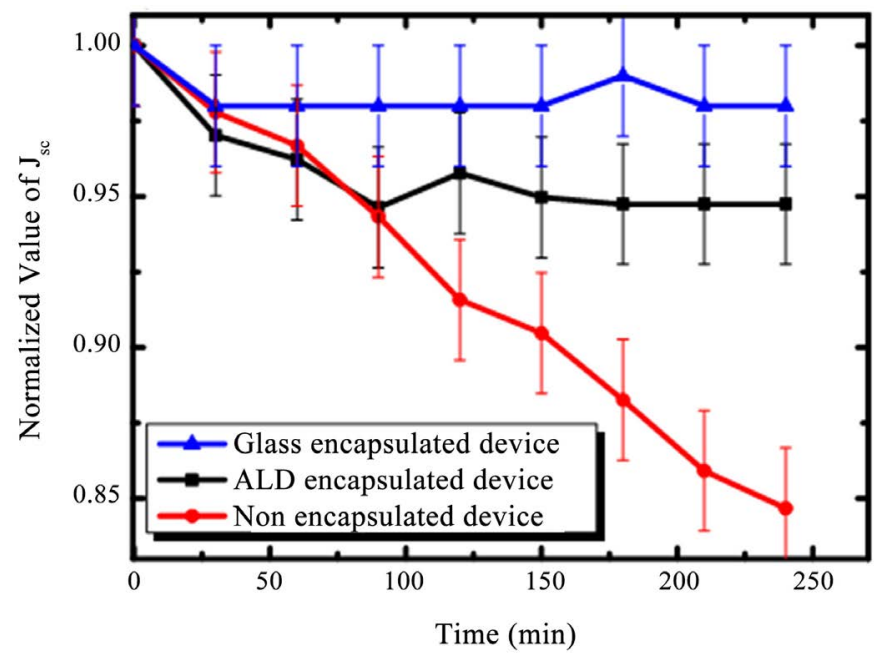

Figure 8. Evolution of $\mathrm{J}_{\mathrm{SC}}$ for the devices encapsulated and unencapsulated [2].

\section{Conclusions}

We have shown in this work that:

- The presence of moisture within the active layer of OPVCs initiates a stronger recombination process, which decreases the ability of charge generation in the bulk-heterojunction area.

- The water encroachment via diffusion into the functional area induces the charge recombination and thus eliminates photocurrent, although the unaffected region is still functional. In addition, the interface of cathode/organic in OPVs is thermally unstable.

- Even after encapsulation, the rapid drop of the performances from the first hours of exposure to light is revealing of the first phase of degradation due to the interfaces electrical degradation as described in our latest article.

- This first rapid phase of degradation is associated with an initial passivation 
at organic/cathode interface, an inevitable process due to the presence of residual oxygen, moisture and other impurities.

- Quantitatively, $\mathrm{J}_{\mathrm{SC}}$ drops dramatically, causing a final decline in PCE, until the catastrophic failure after 400 hours. The short circuit current is kept decreasing during this period, while little reduction in $\mathrm{V}_{\mathrm{OC}}$ and FF is observed. $\mathrm{J}_{\mathrm{SC}}$ is stable for the encapsulated devices, whereas it progressively decreases for the unencapsulated devices. This stability of $\mathrm{J}_{\mathrm{SC}}$ induces the stability of the power conversion efficiency during the experimentation period.

- We remark that among both encapsulation methods used, the glass encapsulation is very effective. However, ALD encapsulation has shown that the alumina slim layer already forms a barrier to the moisture and oxygen even if it abode insufficient to reach the satisfactory lifetime of the devices. But, the ALD approach can be exploited to encapsulate flexible PV devices with the industrially required high throughput.

For future work, we orient our research toward the encapsulant which will resist long time to moisture, oxygen, water and light.

\section{Acknowledgements}

I grateful to Professor Jean Chabi Orou-Bio, Basile Bruno Kounouhewa, Dr. Mamadou Ossénatou, Dr. Gabin KOTO N’GOBI, and Dr. Macaire Agbomahena for fruitful discussions. We acknowledge Dr. Saliou Amoussa Hounkpatin, Pdg Isaac T. Madogni, and "Laboratory for Chemistry of Novel Materials, University of Mons (UMONS)/Materia Nova R\&D Center, Place du Parc 20, B-7000 Mons, Belgium".

\section{Conflicts of Interest}

The authors declare no conflicts of interest regarding the publication of this paper.

\section{References}

[1] Madogni, V.I., Kounouhéwa, B., Akpo, A., Agbomahéna, M., Hounkpatin, S.A. and Awanou, C.N. (2015) Comparison of Degradation Mechanisms in Organic Photovoltaic Devices upon Exposure to a Temperate and a subequatorial Climate. Chemical Physics Letters, 640, 201-214. https://doi.org/10.1016/j.cplett.2015.09.023

[2] Agbomahéna, M., Douhéret, O., Kounouhéwa, B., Vianou, A., Awanou, C.N. and Lazzaroni, R. (2013) Ageing of Organic Photovoltaic Devices in Benin Environment (South-Sudanese Climate). Solar Energy Materials and Solar Cells, 117, 93-97. https://doi.org/10.1016/j.solmat.2013.05.005

[3] Wang, X., Zhao, C.X., Xu, G., Chen, Z.K. and Zhu, F. (2012) Degradation Mechanisms in Organic Solar Cells: Localized Moisture Encroachment and Cathode Reaction. Solar Energy Materials and Solar Cells, 104, 1-6. https://doi.org/10.1016/j.solmat.2012.04.038

[4] Gevorgyan, S.A., Medford, A., Bundgaard, E., Sapkota, S., Schleiermacher, H., Zimmermann, B., Wurfel, U., Chafiq, A., Lira-Cantu, M., Swonke, T., Wagner, M., Brabec, C.J., Haillant, O., Voroshazi, E., Aernouts, T., Steim, R., Hauch, J.A., Elsch- 
ner, A., Pannone, M., Xiao, M., Langzettel, A., Laird, D., Lloyd, Rath, M.T., Maier, T., Trimmel, E., Hermenau, G., Menke, M., Leo, T., Rosch, K., Seeland, R., Hoppe, M., Nagle, H., Burke, T.J., Fell, K.B., Vak, C.J., Singh, D., Watkins, T.B., Galagan, S.E., Manor, A., Katz, E.A., Kim, T., Kim, K., Sommeling, P.M., Verhees, W.J.H., Veenstra, S.C., Riede, M., Christoforo, M.G., Currier, T., Shrotriya, V., Schwartz, G. and Krebs, F.C. (2011) An Inter-Laboratory Stability Study of Roll-to-Roll Coated Flexible Polymer Solar Modules. Solar Energy Materials and Solar Cells, 95, 1398-1416. https://doi.org/10.1016/j.solmat.2011.01.010

[5] Tanenbaum, D.M., Hermenau, M., Voroshazi, E., Lloyd, M.T., Galagan, Y., Zimmermann, B., Hosel, M., Dam, H.F., Jørgensen, M., Gevorgyan, S.A., Kudret, S., Maes, W., Lutsen, L., Vanderzande, D., Wurfel, U., Andriessen, R., Rosch, R., Hoppe, H., Escobar, G.T., Cantu, M.L., Rivaton, A., Uzunoglu, G.Y., Germack, D., Andreasen, B., Madsen, M.V., Norrmany, K. and Krebs, F.C. (2012) The ISOS-3 Inter-Laboratory Collaboration Focused on the Stability of a Variety of Organic Photovoltaic Devices. RSC Advances, 2, 882-893. https://doi.org/10.1039/C1RA00686J

[6] Jørgensen, M., Norrman, K., Gevorgyan, S.A., Tromholt, T., Andreasen, B. and Krebs, F.C. (2012) Stability of Polymer Solar Cells. Advanced Materials, 24, 580-612. https://doi.org/10.1002/adma.201104187

[7] Jorgensen, M., Norrman, K. and Krebs, F.C. (2008) Stability/Degradation of Polymer Solar Cells. Solar Energy Materials and Solar Cells, 92, 686-714. https://doi.org/10.1016/j.solmat.2008.01.005

[8] Neugebauer, H., Brabec, C., Hummelen, J.C. and Sariciftci, N.S. (2000) Stability and Photodegradation Mechanisms of Conjugated Polymer/Fullerene Plastic Solar Cells. Solar Energy Materials and Solar Cells, 61, 35-42. https://doi.org/10.1016/S0927-0248(99)00094-X

[9] Jeranko, T., Tributsch, H., Sariciftci, N.S. and Hummelen, J.C. (2004) Patterns of Efficiency and Degradation of Composite Polymer Solar Cells. Solar Energy Materials and Solar Cells, 83, 247-262. https://doi.org/10.1016/j.solmat.2004.02.028

[10] Kawano, K., Pacios, R., Poplavskyy, D., Nelson, J., Bradley, D.D.C. and Durrant, J.R. (2006) Degradation of Organic Solar Cells Due to Air Exposure. Solar Energy Materials and Solar Cells, 90, 3520-3530. https://doi.org/10.1016/j.solmat.2006.06.041

[11] Hsieh, C.H., Cheng, Y.J., Li, P., Chen, C., Dubosc, M., Liang, R. and Hsu, C. (2010) Highly Efficient and Stable Inverted Polymer Solar Cells Integrated with a Cross-Linked Fullerene Material as an Interlayer. Journal of the American Chemical Society, 132, 4887-4893. https://doi.org/10.1021/ja100236b

[12] Kawano, K. and Adachil, C. (2010) Reduced Initial Degradation of Bulk Heterojunction Organic Solar Cells by Incorporation of Stacked Fullerene and Lithium Fluoride Interlayers. Applied Physics Letters, 96, Article ID: 053307. https://doi.org/10.1063/1.3297876

[13] Conings, B., Bertho, S., Vandewal, K., Senes, A., D’Haen, J., Manca, J. and Janssen, R.A.J. (2010) Modeling the Temperature Induced Degradation Kinetics of the Short Circuit Current in Organic Bulk Heterojunction Solar Cells. Applied Physics Letters, 96, Article ID: 163301. https://doi.org/10.1063/1.3391669

[14] Norrman, K., Gevorgyan, S.A. and Krebs, F.C. (2009) Water-Induced Degradation of Polymer Solar Cells Studied by $\mathrm{H}_{2}{ }^{18} \mathrm{O}$ Labeling. ACS Applied Materials and Interfaces, 1, 102-112. https://doi.org/10.1021/am800039w

[15] Seemann, A., Egelhaaf, H.J., Brabec, C.J. and Hauch, J.A. (2009) Influence of Oxygen on Semi-Transparent Organic Solar Cells with Gas Permeable Electrodes. Organic Electronics, 10, 1424-1428. https://doi.org/10.1016/j.orgel.2009.08.001 
[16] Reese, M.O., Morfa, A.J., White, M.S., Kopidakis, N., Shaheen, S.E., Rumbles, G. and Ginley, D.S. (2008) Pathways for the Degradation of Organic Photovoltaic P3HT: PCBM Based Devices. Solar Energy Materials and Solar Cells, 92, 746-752. https://doi.org/10.1016/j.solmat.2008.01.020

[17] Yang, X., Loos, J., Veenstra, S.C., Verhees, W.J.H., Wienk, M.M., Kroon, J.M., Michels, M.A.J. and Janssen, R.A.J. (2005) Nanoscale Morphology of High-Performance Polymer Solar Cells. Nano Letters, 5, 579-583. https://doi.org/10.1021/nl048120i

[18] Lüer, L., Egelhaaf, H.J., Oelkrug, D., Cerullo, G., Lanzani, G., Huisman, B.H. and de Leeuw, D. (2004) Oxygen-Induced Quenching of Photoexcited States in Polythiophene Films. Organic Electronics, 5, 83-89. https://doi.org/10.1016/j.orgel.2003.12.005

[19] Ryu, M.S., Cha, H.J. and Jang, J. (2010) Improvement of Operation Lifetime for Conjugated Polymer/Fullerene Organic Solar Cells by Introducing a UV Absorbing Film. Solar Energy Materials and Solar Cells, 94, 152-156. https://doi.org/10.1016/j.solmat.2009.08.011

[20] Sun, H., Weickert, J., Hesse, H.C. and Mende, L.S. (2011) UV Light Protection through $\mathrm{TiO}_{2}$ Blocking Layers for Inverted Organic Solar Cells. Solar Energy Materials and Solar Cells, 95, 3450-3454. https://doi.org/10.1016/j.solmat.2011.08.004

[21] Engmann, S., Machalett, M., Turkovic, V., Rösch, R., Rädlein, E., Gobsch, G. and Hoppe, H. (2012) Photon Recycling across a Ultraviolet-Blocking Layer by Luminescence in Polymer Solar Cells. Journal of Applied Physics, 112, Article ID: 034517. https://doi.org/10.1063/1.4745016

[22] Schuller, S., Schilinsky, P., Hauch, J. and Brabec, C.J. (2004) Determination of the Degradation Constant of Bulk Heterojunction Solar Cells by Accelerated Lifetime Measurements. Applied Physics A, 79, 37-40. https://doi.org/10.1007/s00339-003-2499-4

[23] Kaltenbrunner, M., White, M.S., Glowacki, E.D., Sekitani, T., Someya, T., Sariciftci, N.S. and Bauer, S. (2012) Ultrathin and Lightweight Organic Solar Cells with High Flexibility. Nature Communications, 3, 770. https://doi.org/10.1038/ncomms1772

[24] Leterrier, Y. (2003) Durability of Nanosized Oxygen-Barrier Coatings on Polymers. Progress in Materials Science, 48, 1-55. https://doi.org/10.1016/S0079-6425(02)00002-6

[25] Sobrinho, A.S.S., Latreche, M., Czeremuszkin, G., Sapieha, J.E.K. and Wertheimer, M.R. (1998) Transparent Barrier Coatings on Polyethylene Terephthalate by Singleand Dual-Frequency Plasma-Enhanced Chemical Vapor Deposition. Journal of Vacuum Sciences and Technology A, 16, 3190-3198.

https://doi.org/10.1116/1.581519

[26] Dennler, G., Lungenschmied, C., Neugebauer, H., Sariciftci, N.S. and Labouret, A. (2005) Flexible, Conjugated Polymer-Fullerene-Based Bulk-Heterojunction Solar Cells: Basics, Encapsulation, and Integration. Journal of Materials Research, 20, 3224-3233. https://doi.org/10.1557/jmr.2005.0399

[27] Potscavage, W.J., Yoo, S., Domercq, B. and Kippelen, B. (2007) Encapsulation of Pentacene/C60 Organic Solar Cells with $\mathrm{Al}_{2} \mathrm{O}_{3}$ Deposited by Atomic Layer Deposition. Applied Physics Letters, 90, Article ID: 253511. https://doi.org/10.1063/1.2751108

[28] Sarkar, S., Culp, J.H., Whyland, J.T., Garvan, M. and Misra, V. (2010) Encapsulation of Organic Solar Cells with Ultrathin Barrier Layers Deposited by Ozone-Based Atomic Layer Deposition. Organic Electronics, 11, 1896-1900. https://doi.org/10.1016/j.orgel.2010.08.020 
[29] Toniolo, R. and Hummelgen, I.A. (2004) Simple and Fast Organic Device Encapsulation Using Polyisobutene. Macromolecular Materials Engineering, 289, 311-314. https://doi.org/10.1002/mame.200300329

[30] Agroui, K. and Collins, G. (2003) Characterisation of EVA Encapsulant Material by Thermally Stimulated Current Technique. Solar Energy Materials and Solar Cells, 80, 33-45. https://doi.org/10.1016/S0927-0248(03)00112-0

[31] Ravichandran, J., Manoj, A.G., Liu, J., Manna, I. and Carroll, D.L. (2008) A Novel Polymer Nanotube Composite for Photovoltaic Packaging Applications. Nanotechnology, 19, Article ID: 085712. https://doi.org/10.1088/0957-4484/19/8/085712

[32] Agroui, K., Belghachi, A., Collins, G. and Farenc, J. (2007) Quality Control of EVA Encapsulant in Photovoltaic Module Process and Outdoor Exposure. Desalination, 209, 1-9. https://doi.org/10.1016/j.desal.2007.04.001

[33] Sondergaard, R.R., Makris, T., Lianos, P., Manor, A., Katz, E.A., Gong, W., Tuladhar, S.M., Nelson, J., Tuomi, R., Sommeling, P., Veenstra, S.C., Rivaton, A., Dupuis, A., Escobar, G.T., Cantu, M.L., Sapkota, S.B., Zimmermann, B., Wurfel, U., Matzarakis, A. and Krebs, F.C. (2012) The Use of Polyurethane as Encapsulating Method for Polymer Solar Cells-An Inter Laboratory Study on Outdoor Stability in 8 Countries. Solar Energy Materials Solar Cells, 99, 292-300. https://doi.org/10.1016/j.solmat.2011.12.013

[34] Charton, C., Schiller, N., Fahland, M., Hollander, A., Wedel, A. and Noller, K. (2006) Development of High Barrier Films on Flexible Polymer Substrates. Thin Solid Films, 502, 99-103. https://doi.org/10.1016/j.tsf.2005.07.253

[35] Chwang, A.B., Rothman, M.A., Mao, S.Y., Hewitt, R.H., Weaver, M.S., Silvernail, J.A., Rajan, K., Hack, M., Brown, J.J., Chu, X., Moro, L., Krajewski, T. and Rutherford, N. (2003) Thin Film Encapsulated Flexible Organic Electroluminescent Displays. Applied Physics Letters, 83, 413. https://doi.org/10.1063/1.1594284

[36] Norrman, K., Larsen, N.B. and Krebs, F.C. (2006) Lifetimes of Organic Photovoltaics: Combining Chemical and Physical Characterisation Techniques to Study Degradation Mechanisms. Solar Energy Materials and Solar Cells, 90, 2793-2814. https://doi.org/10.1016/j.solmat.2006.04.009

[37] Van Delft, J.A., Alonso, D.G. and Kessels, W.M.M. (2012) Atomic Layer Deposition for Photovoltaics: Applications and Prospects for Solar Cell Manufacturing. Semiconducteur Science and Technology, 27, Article ID: 074002. https://doi.org/10.1088/0268-1242/27/7/074002

[38] Dennler, G., Lungenschmied, C., Neugebauer, H., Sariciftci, N.S., Latreche, M., Czeremuszkin, G. and Wertheimer, M.R. (2006) A New Encapsulation Solution for Flexible Organic Solar Cells. Thin Solid Films, 511, 349-353.

https://doi.org/10.1016/j.tsf.2005.12.091

[39] Madakasira, P., Inoue, K., Ulbricht, R., Lee, S.B., Zhou, M., Ferraris, J.P. and Zakhidov, A.A. (2005) Multilayer Encapsulation of Plastic Photovoltaic Devices. Synthetic Metals, 155, 332-335. https://doi.org/10.1016/j.synthmet.2005.09.035

[40] Lungenschmied, C., Dennler, G., Neugebauer, H., Sariciftci, N.S., Glatthaar, M., Meyer, T. and Meyer, A. (2007) Flexible, Long-Lived, Large-Area, Organic Solar Cells. Solar Energy Materials and Solar Cells, 91, 379-384. https://doi.org/10.1016/j.solmat.2006.10.013

[41] Pathak, D., Bedi, R.K., Kaur, D. and Kumar, R. (2010) Fabrication of Densely Distributed Silver Indium Selenide Nanorods by Using Ag+ Ion Irradiation. Journal of the Korean Physical Society, 57, 474-479. https://doi.org/10.3938/jkps.57.474

[42] Pathak, D., Bedi, R.K. and Kaur, D. (2010) Effect of Substrate Temperature on the 
Structural, Optical, and Electrical Properties of Silver-Indium-Selenide Films Prepared by Using Laser Ablation. Journal of the Korean Physical Society, 56, 836-841. https://doi.org/10.3938/jkps.56.836

[43] Pathak, D., Wagner, T., Adhikari, T. and Nunzi, J.M. (2015) AgInSe 2 .PCBM.P3HT Inorganic Organic Blends for Hybrid Bulk Heterojunction Photovoltaics. Synthetic Metals, 200, 102-108. https://doi.org/10.1016/j.synthmet.2015.01.001

[44] Pathak, D., Wagner, T., Adhikari, T. and Nunzi, J.M. (2015) Photovoltaic Performance of $\mathrm{AgInSe}_{2}$-Conjugated Polymer Hybrid System Bulk Heterojunction Solar Cells. Synthetic Metals, 199, 87-92. https://doi.org/10.1016/j.synthmet.2014.11.015

[45] Hermenau, M., Schubert, S., Klumbies, H., Fahlteich, J., Meskamp, L.M., Leo, K. and Riede, M. (2012) The Effect of Barrier Performance on the Lifetime of Small-Molecule Organic Solar Cells. Solar Energy Materials and Solar Cells, 97, 102-108. https://doi.org/10.1016/j.solmat.2011.09.026

[46] Park, B., Kim, Y.J., Graham, S. and Reichmanis, E. (2011) Change in Electronic States in the Accumulation Layer at Interfaces in a Poly(3-Hexylthiophene) Field-Effect Transistor and the Impact of Encapsulation. ACS Applied Materials Interfaces, 3, 3545-3551. https://doi.org/10.1021/am200760m

[47] Weaver, M.S., Michalski, L.A., Rajan, K., Rothman, M.A., Silvernail, J.A., Burrows, P.E., Graff, G.L., Gross, M.E., Martin, P.M., Hall, M., Mast, E., Bonham, C., Bennett, W. and Zumhoff, M. (2002) Organic Light-Emitting Devices with Extended Operating Lifetimes on Plastic Substrates. Applied Physic Letters, 81, 2929.

https://doi.org/10.1063/1.1514831

[48] Jang, J.H., Parck, J.H. and Oh, S.G. (2009) Methods for Improving the Lifetime Performance of Organic Photovoltaics with Low-Costing Encapsulation. Materials Research Bulletin, 44, 110-118.

[49] Kim, S.H., Lee, H.C., Kim, W.Y., Park, J.W., Chung, J.W., Ahn, S.W. and Lee, H.M. (2011) Performance Improvement of Microcrystalline Thin Film Silicon Solar Cells by Back Reflector with High Resistivity and Low Absorption. 37 th IEEE Photovoltaic Specialists Conference, Seattle, WA, 19-24 June 2011.

[50] Kuwabara, T., Nakayama, T., Uozumi, K., Yamaguchi, T. and Takahashi, K. (2008) Highly Durable Inverted-Type Organic Solar Cell Using Amorphous Titanium Oxide as Electron Collection Electrode Inserted between ITO and Organic Layer. Solar Energy Materials and Solar Cells, 92, 1476-1482. https://doi.org/10.1016/j.solmat.2008.06.012

[51] Medford, A.J., Lilliedal, M.R., Jorgensen, M., Aaro, D., Pakalski, H., Fyenbo, J. and Krebs, F.C. (2010) Grid-Connected Polymer Solar Panels: Initial Considerations of Cost, Lifetime, and Practicality. Optics Express, 18, A272-A285. https://doi.org/10.1364/OE.18.00A272

[52] Grossiord, N., Kroon, J.M., Andriessen, R. and Blom, P.W. (2012) Degradation Mechanisms in Organic Photovoltaic Devices. Organic Electronics, 13, 432-456. https://doi.org/10.1016/j.orgel.2011.11.027

[53] Peters, C.H., Quintana, I.T.S., Kastrop, J.P., Beaupre, S., Leclerc, M. and Mc Gehee, D. (2011) High Efficiency Polymer Solar Cells with Long Operating Lifetimes. Advanced Energy Materials, 1, 491-494. https://doi.org/10.1002/aenm.201100138

[54] Tanenbaum, D.M., Dam, H.F., Rosch, R., Jorgensen, M., Hoppe, H. and Krebs, F.C. (2012) Edge Sealing for Low Cost Stability Enhancement of Roll-to-Roll Processed Flexible Polymer Solar Cell Modules. Solar Energy Materials and Solar Cells, 97, 157-163. https://doi.org/10.1016/j.solmat.2011.09.064 
[55] Sapkota, S.B., Spies, A., Zimmermann, B., Dürr, I. and Würfel, U. (2014) Promising Long-Term Stability of Encapsulated ITO-Free Bulk-Heterojunction Organic Solar Cells under Different Aging Conditions. Solar Energy Materials and Solar Cells, 130, 144-150. https://doi.org/10.1016/j.solmat.2014.07.004

[56] Hosel, M., Sondergaard, R., Jorgensen, M. and Krebs, F.C. (2013) Comparison of UV-Curing, Hotmelt, and Pressure Sensitive Adhesive as Roll-to-Roll Encapsulation Methods for Polymer Solar Cells. Advanced Engineering Materials, 15, 1068-1075. https://doi.org/10.1002/adem.201300172

[57] Krebs, F.C., Hosel, M., Corazza, M., Roth, B., Madsen, M.V., Gevorgyan, S.A., Sondergaard, R., Karg, D. and Jorgensen, M. (2013) Freely Available OPV-The Fast Way to Progress. Energy Technology, 1, 378-381.

https://doi.org/10.1002/ente.201300057

[58] Zimmermann, B., Wurfel, U. and Niggemann, M. (2009) Long-Term Stability of Efficient Inverted P3HT:PCBM Solar Cells. Solar Energy Materials and Solar Cells, 93, 491-496. https://doi.org/10.1016/j.solmat.2008.12.022

[59] Wu, S., Li, J., Tai, Q. and Yan, F. (2010) Investigation of High-Performance Air-Processed Poly(3-Hexylthiophene)/Methanofullerene Bulk-Heterojunction Solar Cells. The Journal of Physical Chemistry C, 114, 21873-21877. https://doi.org/10.1021/jp108886p

[60] Vijila, C., Ng, G.M., Tan, M.J., Goh, W.P. and Zhu, F.R. (2009) Imbalanced Charge Mobility in Oxygen Treated Polythiophene/Fullerene Based Bulk Heterojunction Solar Cells. Applied Physics Letters, 95, Article ID: 263305. https://doi.org/10.1063/1.3279135 